that even such "minor" incidents do not have to be tolerated by anyone. In addition, they saw that an individual who chooses to stand up and fight against such behavior is supported by the college, not brushed aside. I now make it a point to conclude my discussion of women's rights by saying that if any of them (even males) are harassed they should feel free to tell faculty or administra- tors because the situation will be taken seriously.

Finally, from a personal perspective, the support given to me made me able to take a step back from the anger and embarrassment. My initial inclination was to try to force the student to withdraw from my class. But now I see that some good has resulted from our discussion. Although institutions cannot keep inci- dents like this from happening, it is comforting to have them respond in such a positive manner.

\section{About the Author \\ Paula Kilcoyne is an assistant professor of government at Bentley College.}

\title{
The Status of Latinos in the Profession: Problems in Recruitment and Retention
}

\author{
Manuel Ávalos, Arizona State/West University
}

In 1970, an ad hoc committee of the American Political Science Association (APSA) published a report on Mexican Americans in the profession (Ad Hoc Committee on Mexican Americans in the Profession, 1970). The committee was concerned about the lack of scholarly work on America's second largest disadvantaged minority group. They were equally concerned about the lack of recruitment and training of Mexican American political scientists. In its report the committee noted that there were only two Mexican American scholars with doctoral degrees in political science in the entire nation and both had left academe for governmental service. The ad hoc committee concluded:

There is something basically wrong with political science when we (1) fail to adequately interpret the political presence of eight or more million people, and (2) when we fail to recruit and train more than a handful of their representatives. This, of course means a substantial loss of our body of knowledge and beyond this, it may represent a serious insensitivity, on our part, to the contemporary problem of mankind. (Ad Hoc Committee on Mexican Americans in the Profession, 1970: 352)

A subsequent study by the Committee on the Status of Chicanos of the Western Political Science Association (1975) of political science departments in institutions in thirteen western and southwestern states reported that the recruitment and retention of Chicanos, as well as course offerings in the area of Chicano politics in the discipline, had not improved.

The WPSA committee noted that while in general most schools perceived a need for more courses, students, and faculty in the area of Chicano politics, most of the schools offered very few suggestions for increasing the numbers of Chicanos in political science departments. The report concluded that most departments were neither interested in changing, nor willing to change their departmental policies for graduate admissions and faculty hiring which had led to the exclusion of Chicanos from the profession. The reason for this reluctance to change was a perceived threat to the academic standards of political science departments even though the exclusionary policies had never been tested with respect to their validity in predicting success or failure of Chicago graduate students or faculty (Committee on the Status of Chicanos, 1975).

While the number of Latino(a) Ph.D.'s has slowly increased since 1970, the WPSA Committee on the Status of Chicanos has identified only 56 Latino(a) Ph.D.'s in academic political science departments as of 1990 . The situation for Latino(a)s within the discipline has changed very little in the last twenty years and serious problems continue to exist. Two of the major problems which Latino(a)s face are in the areas of recruitment and retention (tenure and/or promotion).

\section{Recruitment and Retention of Latinos in Political Science}

Recruitment is a problem which begins at the undergraduate and graduate school level. In the last decade there has been a serious decline in the number of Latino(a)s entering and completing graduate programs in political science. Over the twenty year period between 1970 and 1980 nationwide Ph.D. granting political science programs have graduated a paltry average of less than 3 Latino(a)s per year. Of the fifty-six Latino's holding Ph.D.'s in 1990 (Committee on the Status of Chicanos, 1990) only thirteen (23 percent) have received a Ph.D. since 1980. And as of the fall of 1989 the

Of the fifty-six Latino's holding Ph.D.'s in 1990 only thirteen (23 percent) have received a Ph.D. since 1980.

Committee on the Status of Chicanos of the WPSA has been able to identify only 15 Latino(a) graduate students in Ph.D. programs across the United States. 
More alarming is the fact that very few women are entering and or completing Ph.D. programs. There are currently only five Latinas in academic political science departments (one other is in a department of Chicano Studies). Of the six Latina political scientists, only two have received a Ph.D. in the decade of the 1980 s.

Once a Latino(a) is hired for a tenure track position he/she often faces problems that are different from non-minority faculty in his/her attempt to secure tenure and promotion. A recent study by Aguirre (1987) concludes that universities often sort and channel Chicano(a) faculty into a limited opportunity structure (mainly minority oriented service activities) on the periphery of the mainstream activities of the postsecondary organization and therefore Latino(a) faculty often find themselves socially and academically isolated within the university institution.

Academic isolation in political science departments in part exists due to the Latino(a) faculty members' non-mainstream research interests, and a lack of junior-senior mentor relationships, often essential for academic integration into the world of professional refereed journals and the development of grantsmanship skills. Early success in publishing in refereed journals and the securing of grant funds to buy out teaching release time is crucial for successful tenure and promotion for the junior faculty member. While these are problems which all junior faculty face they may be somewhat exacerbated for the Latino(a) researcher.

In most universities whose primary mission is research rather than teaching, criteria for tenure and promotion usually implicitly or explicitly require some publications in professional refereed mainstream journals in political science. Yet very few articles on race and ethnicity seem to be published in these journals. For the Latino(a) researcher this creates a serious obstacle to establishing a high profile publication record which is necessary for successful retention and promotion in most research oriented political science departments. Where does a Latino(a) political scientist submit articles for publication if mainstream journals do not seem to be publishing articles on minority re- search topics? Is the problem one of the insignificance of race in political science as opposed to other social science disciplines, or is it a problem of the insensitivity on the part of the discipline of political science to race and ethnic research in general?

\section{Where does a Latino(a) political scientist submit articles for publication if mainstream journals do not seem to be publishing articles on minority research topics?}

\section{The Declining Significance of Race or Insignificance of Race in Political Science Research?}

Of primary concern here is the historical record of the publication of research on race and ethnic politics in political science journals. And second, how does the discipline of political science compare with other social science disciplines, such as sociology, on the publication of research on race and ethnicity?

\section{Data and Methods}

The data for this comparison consist of all journal articles ${ }^{1}$ published between 1964-1988 in what are generally recognized as the most prestigious mainstream journals ${ }^{2}$ in the disciplines of political science and sociology, and one interdisciplinary social science journal.

Articles for the period of 1964-1988 were operationalized into the following four categories: (1) articles whose major hypothesis(es) or research question(s) specifically focused on social and political problems of the Latino community; (2) articles whose major hypothesis(es) or research question(s) focused on social and political problems of the Black community; (3) articles whose major hypothesis(es) or major research question(s) focused on women's social and political (gender related) issues; and (4) articles whose major hypothesis(es) or research question(s) did not focus on one specific ethnic or racial group (e.g., Blacks, Latinos, Asians) but which either focused on a comparison of social and political problems among several ethnic groups or which focused on the general topic of ethnicity.

Articles on women's issues were analyzed for two reasons. First, many female academicians feel that women's topics of research are nonmainstream topics in the discipline of political science. Therefore I wanted to test the hypothesis that research on female (gender) issues would be no more likely to be published in mainstream political science journals than research on race or ethnicity. Second, I wanted to see if any articles combined race and gender topics. Unfortunately, I did not find a single article published in any of the political science journals which combined an analysis of issues on gender and race during the period of analysis; however, I did identify twenty-five articles which combined an analysis of issues on gender and race in sociology journals. Due to the fact that the primary focus of these articles were on gender issues, with race being of secondary importance, these articles were included in the women's article category for the purpose of my analysis.

\section{Analysis}

Table 1 presents a comparison of percentages (raw numbers are found in parentheses) of published articles on race, ethnic and gender issues for the period of 1964-1988 in seven selected political science and sociology journals and one interdisciplinary journal. From the period of 1964 to 1988 only eleven articles have ever been published on the Latino community in the four selected political science journals. Only one article on the Latino community has ever been published in a major political science journal other than the Western Political Quarterly (WPQ). ${ }^{3}$ Articles which focus on Blacks, women and ethnicity are almost as poorly represented in political science journals as are articles on the Latino community. In none of the four political science journals does the publication of articles on race, gender and 
TABLE 1.

Comparison of Publications of Race, Ethnic, and Gender Articles in Selected Political Science and Sociology Journals, 1964-1988

\begin{tabular}{lcccc}
\hline Journal & $\begin{array}{c}\text { Percent } \\
\text { Hispanic } \\
\text { Articles }\end{array}$ & $\begin{array}{c}\text { Percent } \\
\text { Black } \\
\text { Articles }\end{array}$ & $\begin{array}{c}\text { Percent } \\
\text { Women } \\
\text { Articles }\end{array}$ & $\begin{array}{c}\text { Percent } \\
\text { Race/Ethnic } \\
\text { Articles }\end{array}$ \\
\hline American Political Science Review & 0.0 & 0.7 & 0.5 & 0.8 \\
Journal of Politics & $(0)$ & $(7)$ & $(5)$ & $(8)$ \\
American Journal of Political Science & 0.0 & 2.4 & 1.4 & 2.9 \\
Western Political Quarterly & $(1)$ & $(19)$ & $(11)^{\mathrm{a}}$ & $(23)$ \\
American Sociological Review & 0.0 & 1.0 & 1.6 & 1.9 \\
American Journal of Sociology & $(0)$ & $(8)$ & $(13)$ & $(15)$ \\
Social Forces & 0.8 & 1.2 & 2.9 & 1.2 \\
Social Science Quarterly & $(9)$ & $(13)$ & $(31)^{\mathrm{b}}$ & $(12)$ \\
& 0.7 & 2.9 & 5.7 & 5.4 \\
& $(9)$ & $(36)$ & $(71)$ & $(67)$ \\
& 1.9 & 5.1 & 9.2 & 7.6 \\
& $(19)$ & $(49)$ & $(89)$ & $(74)$ \\
\end{tabular}

${ }^{a}$ Vol. 41 , no. 2 special issue: Symposium on Women and Politics (7 articles).

${ }^{b}$ Vol. 34, no. 1 special issue: Women and Politics (13 articles).

${ }^{\mathrm{c}}$ Vol. 53 , no. 4 special issue: Chicano Experience in the U.S. (22 articles); Vol. 65, no. 2 special issue: The Mexican Origin Experience ( 35 articles).

${ }^{\mathrm{d}}$ Vol. 49 , no. 3 special issue: Black America (30 articles); Vol. 57, no. 4 special issue: New Perspectives on Black America (9 articles).

ethnicity exceed three percent of all articles published in these journals for the twenty-five year period examined.

\section{From the period of 1964}

to 1988 only eleven articles have ever been published on the Latino community in the four selected political science journals.

Articles on race, gender and ethnicity in sociology journals fare much better than in political science journals. Three times as many articles focusing on the Latino community have been published in the three leading sociology journals as have been published in four of the leading journals in political science. It is also apparent that articles on women's issues and ethnicity are much more likely to be published in sociology journals than in political science journals. Table 1 also shows that the Social Science Quarterly (SSQ) has the best overall publication record of articles on Latinos and Blacks.

Table 2 more dramatically illustrates the major differences in the publication records of articles on race, gender and ethnicity between sociology and political science journals during the last twenty five years. If we combine the percentage of all articles on race, gender and ethnicity for each journal over the twenty five year period we find that sociology journals have consistently published a much higher percentage of these articles than have political science journals. The American Sociological Review (ASR), and the American Journal of Sociology (AJS), two of the most prestigious journals in sociology, have published between seven and ten times as many articles on race, ethnicity and gender as has the American Political Science Review (APSR). And while the Journal of Politics (JOP) and the American journal of Political Science (AJPS) have higher percentages of publications of articles on race, gender and ethnicity than the $A P S R$, these percentages are still two to three times lower than any of the percentages for the three sociology journals used in our analysis.

To further illustrate differences in the number of publications of articles on race, gender and ethnicity between political science and sociology journals a comparison of group means test was performed. Here we are testing the hypothesis that there is a statistical difference between the mean percentage of articles published on race, gender and ethnicity (over the twenty five year period) when articles are divided into two groups: (1) those published in the four political science journals (APSR, JOP, $A J P S$ and $W P Q$ ) and; (2) those published in the three sociology journals (AJS, ASR, and Social Forces) for the period of 1964-1988.

It is apparent from the results of the group means test (Table 3 ) that there are statistically significant differences in the publication rates of articles on race, gender and ethnicity between our two groups. Publications on race, gender and ethnicity are significantly more likely to be published in sociology journals than in political science journals.

Publications on race, gender and ethnicity are significantly more likely to be published in sociology journals than in political science journals.

An anomaly that exists in Table 1 with regard to publication of research on the Latino community in the $W P Q$ deserves further discussion. One might wonder why all but one article on the Latino community has been published in the $W P Q$ ? In 1975 the Western Political Science Association (WPSA) established Chicano, Black and Women caucuses within the organization. Through the efforts of these caucuses a unique "best" paper competition was established at the annual meetings of the WPSA. This competition is unique from other "best" paper competitions in 
TABLE 2.

Total Percentages of Race, Ethnic and Gender Articles for Selected

Political Science and Sociology

Journals, 1964-1988

\begin{tabular}{lc}
\hline Journal & Percentage \\
\hline American Political Science & \\
Review & 1.9 \\
Journal of Politics & 6.8 \\
American Journal of Political & 4.5 \\
Science & 6.2 \\
Western Political Quarterly & 14.8 \\
American Sociological Review & \\
American Journal of & 23.8 \\
Sociology & 19.8 \\
Social Forces & 30.7 \\
Social Science Quarterly & \\
\hline
\end{tabular}

other political science associations in that a competition for "best" paper occurs within each caucus as well as a "best" paper being awarded for the entire conference outside of these caucuses. The papers which win these "best" paper competitions (and it should be noted that winners have not been awarded every year within each caucus) is guaranteed publication in the Western Political Quarterly if the author so wishes.

Table 4 presents results from a bivariate regression analysis examining the differences in the number of publications on race and gender topics in the WPQ before and after the establishment of the "best paper" competitions for the Black, Chicano and Women caucuses in 1977. A comparison of the unstandardized regression coefficients (b's) shows that publication of articles on Latino and gender topics significantly increased after 1977. Seven of the nine articles published on Latino issues in the WPQ have come on or after 1977 (three are articles which have been awarded "best" paper on Chicano Politics). ${ }^{4}$ This unique situation within the WPSA seems to have had a significant direct or indirect effect on increasing the publication of articles on Latinos and women in the WPQ.

\section{Discussion}

The analysis of the publication of articles on race and ethnic research in political science journals has significant implications for tenure and promotion decisions affecting Latinos in

TABLE 3.

Comparison of Mean Percentage of Articles Published on Race, Ethnicity and Gender in Selected Political Science Journals versus Sociology Journals, 1964-1988

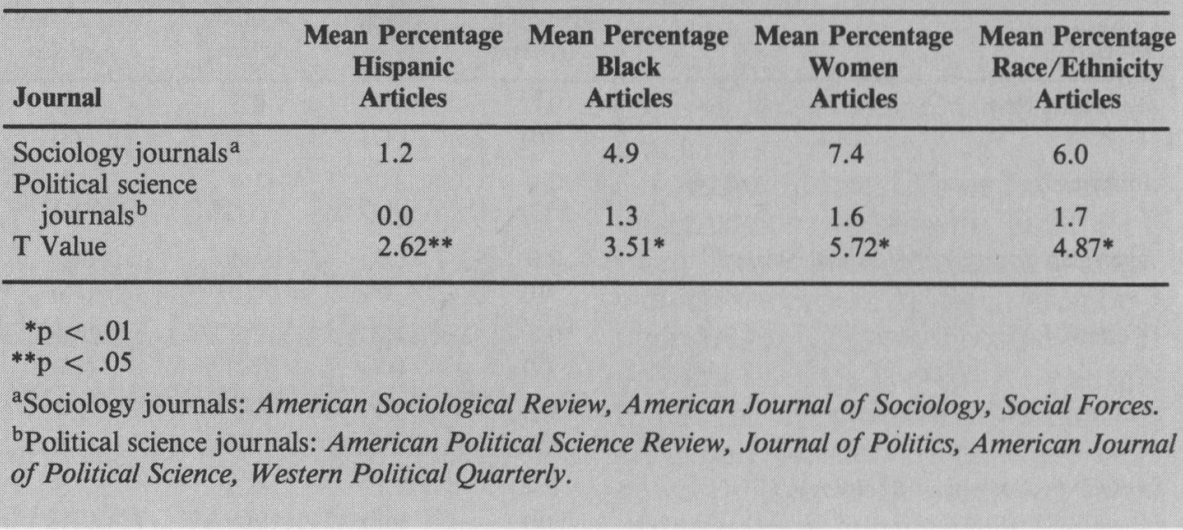

the profession. It raises a number of important questions: Why are so few articles on race and ethnicity being published in the leading journals in political science and why are articles on race and ethnicity much more likely to be published in sociology or interdisciplinary journals than in political science journals? Are race, gender and ethnicity of little importance in analyses of social and political phenomena? This would hardly seem to be the case.

Certainly race and ethnicity have historically been important topics of research among much of the urban policy literature in both sociology and political science (Whyte, 1943; Myrdal, 1944; Gordon, 1961; Banfield and Wilson, 1963; Breton, 1964; Dawson and Robinson, 1965;

Parenti, 1967; Lineberry and Fowler, 1967; Banfield, 1968; Gordon, 1968; Paterson, 1974). And certainly race and ethnicity have periodically been important variables in analyses of community power and voting behavior at the state, local and national level (Dahl, 1961; Wolfinger, 1965, 1966; Levy and Kramer, 1972); Lorinskas, Hawkins, and Edwards, 1969). Race has also been an important variable in the political socialization literature (Engstom, 1970; Greenberg, 1970a, 1970b, 1972; Garcia, 1973, and it is rare today to find a major national survey instrument designed for analyses of social and political behavior that does not include a variety of demographic questions on ethnicity (e.g., identification, country of origin, and language usage).

Why then are so few articles on race and ethnicity found in mainstream political science journals as opposed to sociology journals? There are probably a number of complex reasons. First, while topics of research in political science and sociology sometimes overlap (particularly in studies of political behavior of groups) sociologists have perhaps emphasized the importance of race and ethnicity at a much earlier stage in the development of the discipline

\section{TABLE 4.}

Unstandardized Regression Coefficients (b's) of Intervention Variable ${ }^{a}$ for Hispanic, Black, Female and Race/Ethnic Journal Articles in the Western Political Quarterly, 1964-1988

\begin{tabular}{|c|c|c|c|c|}
\hline & $\begin{array}{l}\text { Hispanic } \\
\text { Articles }\end{array}$ & $\begin{array}{c}\text { Black } \\
\text { Articles }\end{array}$ & $\begin{array}{l}\text { Female } \\
\text { Articles }\end{array}$ & $\begin{array}{c}\text { Race/Ethnic } \\
\text { Articles }\end{array}$ \\
\hline Intervention & .012 & .001 & .048 & .016 \\
\hline Constant & .004 & .013 & .009 & .027 \\
\hline $\mathbf{R}^{2}$ & .16 & .00 & .13 & .04 \\
\hline $\mathrm{N}$ & 25 & 25 & 25 & 25 \\
\hline
\end{tabular}


than has been the case in political science. The study of race and ethnicity in sociology is at least as old as the work of Robert Park and Ernest Burgess (in the early 1900s) of the Chicano school of urban sociology (Park, 1914, 1918; Park, Burgess and McKenzie, 1925).

In political science, however, almost no literature exists prior to the mid 1960 s on race or ethnicity. This absence may be due in part to the fact that the importance of race and ethnicity in political science research seems only to have begun during the period of racial and social unrest between White and Black America in the 1960s and seems to have rapidly vanished in the late 1970 s and 1980s.

Beyond the difference in the historical development of interest in race and ethnicity in the disciplines of sociology and political science is the dominance of a somewhat narrower range of topics in mainstream political science journals as opposed to the more varied range of topics found in sociology journals. It is obvious from any examination of the $A P S R, J O P$, and the $A J P S$ over the last twenty five years that the dominant topic of articles published has been in the area of elections and voting behavior. Yet very few published articles in the APSR, JOP, and $A J P S$ examine the political behavior of Blacks, Latinos, Native Americans or Asians, nor do the majority of these articles use race or ethnicity as important variables in their analyses. Why?

This may in large part be because the primary data used for these analyses, the National Election Survey (NES), has never oversampled any major minority group (e.g., Blacks or Latinos) in the United States so that analyses of ethnic electoral behavior could be done. The field of voting behavior has also almost exclusively limited its collection of data to the national level as opposed to much needed collections of data at the state and local levels which are equally important arenas for studying Latino and Black political behavior.

The problem of available data to analyze race and ethnic issues is not restricted only to the area of political behavior in political science. For example, the longest running panel survey of changes in income in the United States, the Panel Survey of Income Dynamics (PSID), does not at present contain a large enough sample of Latinos or Blacks (or any other minority group) to allow researchers to study such important policy issues as welfare, poverty and unemployment of minority groups. The reality for Latinos is that there are very few national level datasets in political science available to do analyses of Latino social, economic and political behavior.

A final possible explanation for the lack of articles published on race, gender and ethnicity in political science journals is a philosophical and theoretical one, namely the reluctance on the part of the discipline of political science to accept critical (or radical political economy) theory as a legitimate model of analysis of political phenomena.

It is the harsh reality for Latino(a) political scientists, and for Marxist political scientists, that no mainstream journal has ever consistently published articles which use critical theory as their primary method of analysis. In part this may be because the discipline has historically been dominated by institutionalist, political behavior and rational choice approaches and partly because the social and political climates generated by the Cold War have limited the academic freedom of Marxist scholars. Many university professors, including some political scientists, have been denied tenure and promotion for adopting Marxist approaches in their research (Fisk, 1972; Brown, 1979; Frumkin, 1981; Ollman, 1984). Many Latino(a) scholars, especially those trained in the late 1960s and early 1970s, have adopted a critical theory approach to the study of Latino political phenomena (for example see Barerra, 1979), and have very few and limited journals available for submission of their research (e.g., New Left Review, The Social Register, or sociology journals), and none of these journals are considered to be political science journals. These are very real problems which Latino(a) researchers face in their attempt to secure tenure and promotion within the discipline of political science.
Even if Latino(a) political scientists do not utilize political economy approaches in their research they must often resort to submission of their articles to journals such as the $S S Q$, The Social Science Journal, specialty journals such as Urban Affairs Quarterly, policy journals such as Policy Studies Review, or Policy Studies Journal, or other journals outside the discipline of political science. Publications in these journals alone rarely guarantee good chances for tenure and promotion at most major research institutions in political science.

In most research-oriented political science departments, if a junior faculty member does not have articles published in the "right" mainstream political science journals his/ her chances for tenure are slim to none. This fact alone may offer some indication for why only twentyfive percent of Latino political scientists are found in universities whose primary mission is research.

In conclusion, this paper has tried to outline the major problems Latino(a)s face with regard to recruitment and retention in the discipline. The situation of Latino(a)s in these areas has not significantly improved in the last twenty years. Political science departments have not significantly increased the recruitment of Latino(a) graduate students and faculty in the last two decades. Latino(a) political scientists who engage in research in race and ethnic politics continue to suffer from lack of adequate national databases to do mainstream analyses of minority political behavior, and mainstream professional journals in the discipline have a woeful record of publishing articles on Latino/Chicano political topics. If professional organizations and departments in the discipline of political science do not aggressively begin to address the problems outlined in this paper, ten years from now standing minority committees in professional associations may be nonexistent because there will be few of us remaining or entering the profession in the future.

\section{Notes}

1. Research notes were not analyzed since some of the journals in this analysis did not 
use this format and in some cases the use of research notes was intermittent.

2. Political science and sociology journals from which data were collected were:

American Political Science Review, Journal of Politics, American Journal of Political Science, Western Political Quarterly, American Sociological Review, American Journal of Sociol$o g y$, and Social Forces. The interdisciplinary journal included in the analysis was the Social Science Quarterly.

3. The one exception is Luis Fraga, Kenneth Meier and Robert England, "Hispanic Americans and Educational Policy: Limits to Equal Access," Journal of Politics 48 (November, 1986).

4. Two past winners of the "best" paper will be published in volume 42 of the Western Political Quarterly.

\section{References}

Ad Hoc Committee on Mexican Americans in the Profession. 1970. Report of the APSA Committee. PS 3: 739.

Aguirre, Adalberto, Jr. 1987. " An Interpretative Analysis of Chicano Faculty in Academe." The Social Science Journal 24: 71-81.

Banfield, Edward. 1974. The Unheavenly City Revisited. Boston: Little, Brown and Company.

Banfield, Edward and James Q. Wilson. 1963. City Politics. Cambridge: Harvard and M.I.T. University Presses.

Barrera, Mario. 1979. Race and Class in the Southwest. Notre Dame: University of Notre Dame Press.

Breton, Raymond. 1964. "Institutional Completeness of Ethnic Communities and the Personal Relations of Immigrants." American Journal of Sociology 70 : 193-205.

Brown, Michael. 1979. "The Ollman Case and Academic Freedom," New Political Science (Spring): 40-52.

Committee on the Status of Chicanos, Western Political Science Association, 1990.

"Roster of Latino Political Scientists,
1990," unpublished.

Committee on the Status of Chicanos, Western Political Science Association. 1975. "Report on the Status of Chicanos in the Profession, 1974, Western States." Western Political Quarterly 28: 739-743.

Dahl, Robert. 1961. Who Governs? New Haven: Yale University Press.

Dawson, Richard E. and James A. Dawson. 1965. "Ethnicity and State Welfare Policies," in Herbert Jacob and Kenneth Vines (eds.) Politics in American States: $A$ Comparative Analysis. Boston: Little, Brown and Company.

Engstrom, Richard L., "Race and Compliance: Differential Political Socialization." Polity 3: 100-111.

Fisk, Milton. 1972. "Academic Freedom in Class Society," in Edmund Pincoffs (ed.) The Concept of Academic Freedom. Austin: University of Texas Press.

Frumkin, R. M. 1981. "The Eternal Professor: Scott Nearing is Still Teaching." $Z E D E K$ (February): 3-8.

Garcia, F. Chris. 1973. Political Socialization of Chicano Children. New York: Praeger.

Gordon, Daniel N. "Immigrants and Urban Governmental Forms in American Cities, 1933-1960." American Journal of Sociology 24: 158-71.

Gordon, Milton M. 1961. "Assimilation in America: Theory and Reality." Daedalus 105: 263-283.

Greenberg, Edward S. 1970a. "Black Children and the Political System." Public Opinion Quarterly 34: 333-345.

Greenberg, Edward S. 1970b. "Children and Government: A Comparison Across Racial Lines.' Midwest Journal of Political Science 14: 249-275.

Greenberg, Edward S. 1972. "Black Children, Self-Esteem and the Liberation Movement." Politics and Society 2: 293-307.

Levy, Mark R. and Michael S. Kramer. 1972. The Ethnic Factor. New York: Simon and Schuster.

Lorinskas, Robert A., Brett W. Hawkins, and Stephen D. Edwards. 1969. "The Persistence of Ethnic Voting in Urban and Rural Areas: Results From the Controlled Election Method." Social Science Quarterly 49: 891-899.
Lineberry, Robert L., and Edmund P. Fowler. 1967. "Reformism and Public Policies in American Cities." American Political Science Review 61: 701-716.

Myrdal, Gunnar. 1944. An American Dilemma. New York: Harper and Row.

Ollman, Bertell. 1984. "Academic Freedom in America Today: A Marxist View." Monthly Review 35: 24-30.

Patterson, Ernest. 1974. Black City Politics. New York: Dodd, Mead and Company.

Parenti, Michael. 1967. "Ethnic Politics and the Persistence of Ethnic Identification." American Political Science Review 61: 717-726.

Park, Robert E. 1914. "Racial Assimilation in Secondary Groups with Particular Reference to the Negro." American Journal of Sociology 19: 606-623.

Park, Robert E. 1918. "Education in its Relation to the Conflict and Fusion of Cultures: With Special Reference to the Problems of the Immigrant, the Negro, and Missions." Publications of the American Sociological Society 13: 38-63.

Park, Robert E., Ernest Burgess, and Roderick D. McKenzie. 1925. The City. Chicago: The University of Chicago Press.

Whyte, William H. 1943. Street Corner Society. Chicago: University of Chicago Press.

Wolfinger, Raymond E. 1965. "The Development and Persistence of Ethnic Voting." American Political Science Review 59: 896-908.

Wolfinger, Raymond E. 1966. "Some Consequences of Ethnic Politics," in Harmon Zeigler and Kent Jennings (eds.) The Electoral Process. Englewood Cliffs, NJ: Prentice Hall.

\section{About the Author}

Manuel Avalos is an assistant professor of social and behavioral sciences at Arizona State West University. His research focuses on public policy responses to the social welfare problems (wage discrimination, poverty, unemployment, underemployment) of Latinos. 